\title{
Towards a fusion of horizons: Thematic contours for an urban public theological praxis-agenda in South Africa
}

\begin{abstract}
Authors:
Stephan de Beer ${ }^{1}$

Ignatius Swart ${ }^{2}$

\section{Affiliations:}

${ }^{1}$ Centre for Contextual Ministry, University of

Pretoria, South Africa

${ }^{2}$ Research Institute for Theology and Religion, University of South Africa, South Africa

Note:

This article constitutes the second introductory article to the special collection on

'Doing urban public theology in South Africa: Visions, approaches, themes and practices towards a new agenda' in HTS Teologiese Studies/Theological Studies Volume 70, Issue 3, 2014. The collection is the result of the project 'Urban Public Theology', which was initiated by the Institute for Urban Ministry but later expanded to include several academic departments and institutes at the University of Pretoria (UP) and University of South Africa (UNISA).

The leading centres in this regard were the Centre for Contextual Ministry (UP) and the Research Institute for Theology and Religion (UNISA).
\end{abstract}

\section{Correspondence to:}

Stephan de Beer

Email:

stephan.debeer@up.ac.za

Postal address:

PO Box 11047, Tram Shed

0126, South Africa

Dates:

Received: 25 Aug. 2014

Accepted: 25 Oct. 2014

Published: 20 Nov. 2014

Read online:
This article proposes a 'fusion of horizons' in constructing urban public theologies in South Africa. This is done through the introduction of five interrelated themes that have emerged from the on-going knowledge and idea production by a distinguishable counterpoint in contemporary scholarly, intellectual and activist engagement with the urban, in the authors' own South African context but also wider internationally. In advancing a praxis-agenda for urban public theology, the authors subsequently identify the following, albeit not exhaustive, themes: southern urbanisms and the factor of unprecedented urban migration; 'right to the city' and urbanisation from below; a reclaiming of the commons; the making of 'good cities'; and actors of faith in relation to urban social life.

\section{Introduction}

In this article we propose a 'fusion of horizons' in constructing urban public theologies. Our aim is to do so by relating ourselves, very intentionally, to a distinguishable counterpoint in contemporary scholarly, intellectual and activist engagement with the urban, both in our own South African context but also wider internationally.

Against the backdrop of such intentional association, we want to emphasise the fact that this inclination is not meant to disregard the importance of also engaging with actors from the mainstream involved in the arenas of policy-making and knowledge and idea production, both formally and informally. Instead, and in line with the hermeneutical position that we have adopted in our first article in this special collection (see Swart \& De Beer 2014), we have an agenda in mind that will, from an independent and critically-minded position, not shy away from, but engage very seriously with what is produced by actors from the state, civil society and the corporate or private sector in shaping the urban.

At the same time, however, we more precisely want to refer to our agenda as a 'praxis-agenda' that will purposefully contribute to a synergy between theory and action in the context of the urban. As such, while taking into account our qualification in the preceding paragraph, we consciously want this agenda to, from the vantage-point of our hermeneutical outlook and the wisdoms of certain public and particularistic theologies, be co-shaped by the ideas, visions, conceptualisations, methodological orientations and practical agendas that are emanating from the above-mentioned counterpoint. Moreover, our anticipation is that this inclination to be influenced and shaped by the counterpoint, will lead to an ever-deepening urban public theological praxis-agenda giving impetus to action-oriented, problem-solving and normatively inclined discourses 'from below' in which different actors from the urban grass roots - linked to local urban communities of different kinds, urban social movements and not least urban faith communities - will become primary interlocutors.

Through this presentation, we are by no means pretending to be exhausting the range and depth of idea production from the counterpoint but instead, we are merely valuing the identified thematic contours as integral to the development of our own thinking and praxis-agenda. We subsequently identify and introduce five interrelated themes that have emerged in and between disciplines through contributions from the counterpoint position, in response to urban challenges, particularly in relation to the global South: (1) southern urbanisms and the factor of unprecedented urban migration; (2) 'right to the city' and urbanisation from below; (3) a reclaiming of the commons; (4) the making of 'good cities'; and (5) actors of faith and urban social life.

How to cite this article: De Beer, S. \& Swart, I., 2014, 'Towards a fusion of horizons: Thematic contours for an urban public theological praxisagenda in South Africa', HTS Teologiese Studies/Theological Studies 70(3), Art. \#2812, 9 pages. http://dx.doi.org/10.4102/hts.v70i3.2812 Copyright: @ 2014. The Authors. Licensee: AOSIS OpenJournals. This work is licensed under the Creative Commons Attribution License. 


\section{Southern urbanisms and the factor of unprecedented urban migration}

Cities in the global South experience unprecedented inmigration, often marked by informality and attempts by scholars and voices to the left, more generally speaking, to live down the consequences of the colony whilst resisting neo-colonial and neo-liberal forces. In reflecting upon the unique challenges and characteristics of such cities, a new intellectual focus concerned with the phenomenon of 'southern urbanisms' and the consequent task to construct epistemological practices suitable to the challenges arising from this phenomenon has emerged in recent years (see e.g. Pieterse 2014; Tonkiss 2012; Varley 2013). Edgar Pieterse (2014), a prominent South African exponent of this new focus, provides a good example of the kind of critical questioning posed when he states in one of his latest writings:

This reflection is centrally concerned with some fundamental questions: How best can meaningful knowledge about the city be produced? What should we produce knowledge for? And what do these questions mean for the politics of knowledge production in the global South? (p. 1)

Following the scholarly work of Faranak Miraftab, amongst others, Pieterse at one point in his discussion suggests that an element of the new focus might be evident from the way in which a shifting discourse on urban planning has been emerging in disciplines as diverse as development studies, sociology, anthropology, geography and cultural studies. He points out that it is in literature from these disciplines that a shift in scholarship has taken place that today recognises the existence of a range of actors who are, through their everyday practices, shaping city spaces through formal and informal politics. He further specifies this identification as involving 'the emergence of heterogeneous civil society organizations and mundane everyday practices', which he in turn relates to a new search in the literature 'for a conceptual frame that can appreciate the agency of ordinary people amid vast oppressive machines and economic patterns of uneven development' in city contexts.

Importantly, however, Pieterse also cautions against a simplistic and over-romanticised valorisation of popular practices in the realm of informality and/or insurgent agendas (Pieterse 2014:11). For this reason, he continues by advocating the idea of 'Citizen Academies', which, as 'intermediary institutions' located in civil society could be the creators of 'a practical learning space where community activists, volunteers, workers and state-interface officers can be socialized around a spacious conscious methodology of community development' (Pieterse 2014:16-17).

But even more comprehensively than the idea of 'Citizen Academies', Pieterse's ultimate argument resolves around the idea and agenda of 'co-production', as 'a central epistemic practice for research in the global South' on an overall institutional level (Pieterse 2014:19-20). He argues that this should unfold on four levels: first, in the form of 'laboratories' at 'the city level' that would allow practitioners from the state and civil society organisations 'to work with academic researchers to jointly decipher the most urgent questions that require sustained attention' (Pieterse 2014:20); second, in the form of independent 'knowledge institutions' at the 'city-regional scale' - including 'various universities and numerous public bodies' - that would 'systematize the collection of data and various representations of urban patterns and trends' (Pieterse 2014:20-21); third, in the form of 'urban forums' and 'scholarship' on a national level that would foster collaboration between government departments and 'urbanists and social movements to influence the priorities of national policy and institutions geared to enhance research and development in the country' (Pieterse 2014:21-22); and fourth, in the form of 'platforms' on a 'continental' level that would allow 'urban scholars and practitioners' across Africa to 'engage and collaborate' (Pieterse 2014:22).

Leaving Pieterse's visionary agenda at this point, Doug Saunders, in his best seller Arrival city (2011), takes us a step further by presenting an exhilarating and sometimes disturbing picture of urban migration as the greatest migration the world has ever seen. His conclusion is that a third of humanity is on the move and in the process the world of cities, and related politics and economics, are remade entirely.

It is against the backdrop of such unprecedented migration into cities that southern urbanisms are in fact unfolding. While the 19th century has witnessed the urbanisation of Europe and North America, and the 20th century the explosion of Asia and Latin America, the 21st century is predicted to be the century of Africa's urbanisation (see Pieterse \& Parnell 2014). As pointed out by Pieterse, based on research by the United Nations, Africa's urban population is estimated to swell in just 20 years from now 'by 330 million from its present count (in 2011) of 414 million people' (Pieterse 2014:3; see United Nations, Department of Economic and Social Affairs, Population Division [UN-DESA] 2012:12), the majority of which will live in extreme slum conditions (Pieterse 2014:2-3; Pieterse \& Parnell 2014:10-12). Placing this urban revolution further in context, Pieterse and fellow author Susan Parnell observe that, whilst the continent is still only '40 per cent urbanised at present', Africa's city dwellers population already exceeds those of Europe, Australasia, and North and South America. This means that '(o)nly Asia has more people living in cities' (Pieterse \& Parnell 2014:1), but with Africa's urban population expected to treble over the next four decades (UN-DESA 2012:12).

South African cities and towns experience the reality of such massive migrations and its accompanying vulnerabilities on a daily basis. Recent publications such as Diepsloot by Anton Harber (2011), Sanctuary by Christa Kuljian (2013), and Ubuntu, Migration and Ministry: Being Human in a Johannesburg Church by Elina Hankela (2014) explore the realities and effects of migration on local urban communities in Johannesburg. Both Kuljian and Hankela highlight 
the way in which church and theology wrestle to make sense of migration and possible theological responses to it, particularly in a concrete, practical sense.

Migration is often the result of deep vulnerabilities - crossborder migration as a result of war, hunger, natural disasters, or political unrest; or rural-urban migration as a result of perceived economic opportunities that do not exist in similar ways in rural areas. It seems to be the minority of urban migrants that benefit from access to urban resources such as educational or employment opportunities. And although migration often results from vulnerability, it also seems to exasperate the vulnerability of many by intensifying the realities of homelessness, ethnic conflicts and violence, unemployment, and contests over meagre resources.

It is in such contexts of urban migration and vulnerability, in the global South in general, and in South African cities in particular, that a South African urban public theological agenda would do well to ask similar questions as those raised in the already existing intellectual reflection on southern urbanisms: how best can meaningful knowledge about the city be produced from the point of view of public theological engagement? What should such knowledge be produced for? Who should participate in the production or construction of such knowledge? And what will the implications and challenges be for doing theology epistemologically, methodologically and institutionally; for models of theological education; for research collaboration and engagement in inter- and transdisciplinary research with others; and for the engagement of church and theology with urban realities everywhere, but particularly in the global South, and in the cities of South Africa?

Urban theologian Ray Bakke (1997) speaks of God's incarnation as a refugee child in a foreign land, which places Jesus in a similar situation to millions of urban migrants around the globe today. Could our theologies find, affirm and embrace the gift of Jesus in the faces of nameless migrants in urban neighbourhoods across the globe, but also in the cities of South Africa, articulating new knowledge from 'strange' places?

\section{'Right to the city' and urbanisation from below}

As described above, the African urban landscape, despite being the last continent to urbanise, is fast changing with its own sets of challenges. Often accompanied by vast urban informal settlements, resulting from millions constantly migrating to cities, and struggling to make sense of urban management and development in such contexts, it becomes a hotbed for urban debate, urban social movements and urban innovations.

An ongoing tension exists between approaches that seek to eradicate slums and informal settlements on the one hand, through urban management and technocratic approaches, and 'right to the city' approaches on the other hand that advocate for management and development 'from below', not necessarily eradicating slums and informal settlements, but providing land rights and secure tenure, infrastructure and developmental support, whilst affirming people's right to the city.

Against the backdrop of increasing contests for urban space and access to resources exacerbated by on-going massive inmigrations to the cities of the global South, the conceptual relevance of the work of Henri Lefebvre and David Harvey in developing a 'right to the city' discourse to foster strategic action 'from below' should be considered. Lefebvre, as far back as the 1960s, first used the phrase 'right to the city' to decry 'the commodification and privatisation of urban space' in his own country of France (Görgens \& Van Donk 2012:3). He consequently called for 'a new humanism, a new praxis' (Lefebvre 1996:150) that would allow enfranchised inhabitants 'to participate in the use and production of urban space' (Görgens \& Van Donk 2012:3).

David Harvey (2012), in Rebel cities: From the right to the city to the urban revolution, indicates how urban social movements, globally, work with the same frame of mind without necessarily ever having heard of Lefebvre (Harvey 2012:xii). He speaks of the US Social Forum creating a national Right to the City Alliance in 2007, the achievements of urban social movements in Brazil, and countless other movements dealing with homelessness, gentrification and the criminalisation of the poor, in cities across the world (Harvey 2012:xii-xiii) and then concludes that:

... the idea of the right to the city does not arise primarily out of various intellectual fascinations and fads ... It primarily rises up from the streets, out from the neighborhoods, as a cry for help and sustenance by oppressed peoples in desperate times. (Harvey 2012:xiii)

Turning to our own South African context, we could well upheld the work of the Cape Town based Isandla Institute around 'the right to the city' and, more specifically, 'how poor people in South Africa can claim and enjoy that right' (Isandla Institute n.d.). Amongst other initiatives, the Institute hosted a year-long dialogue series in 2011 on what the 'right to the city' could look like in shaping an agenda for urban transformation in South Africa. The initiative involved members of the urban poor as well as urban nongovernmental organisations (NGOs) (Görgens \& Van Donk 2012:6) and led to the identification of three overarching and concrete rights: 'the right to be in the city', 'the right to access city resources and opportunities', and 'the right to citymaking' (Görgens \& Van Donk 2012:12-13).

Yet, also worthwhile to mention is the work of Marie Huchzermeyer, professor at the School of Architecture and Planning at Wits University, in which she has been developing the right to the city approach very specifically in relation to urban slums in the global South. She argues for the participation of slum dwellers in shaping their own futures, in contrast to the technocratic utopias of city administrators and politicians imagining cities without slums in policy 
after policy. In her book Cities with 'slums', she traces flaws and failures of flagship government projects to eradicate slums, from Cape Town to Nairobi, from Zimbabwe to Nigeria, arguing instead for a right to the city approach or an 'urbanisation from below' (Huchzermeyer 2011).

In a similar way to Huchzermeyer, but from deeply disenfranchised positions on the South African urban fringes, social movements such as Abahlali baseMjondolo $(\mathrm{AbM})$ and others also advocate boldly and articulately for their right to the city (see Zikode 2007, 2013). Having written extensively on the AbM movement, social scientist scholar Nigel Gibson, for instance, writes in one of his publications that $\mathrm{AbM}$ 'expresses a kind of Fanonian shift where the geography of experience becomes the geography of reason', in the sense that 'the thinking of the formerly excluded "damned of the earth" - those denied any human worth - now become central to the future of humanity' (Gibson 2008:706-707). Gibson continues by appreciating AbM for the way in which it challenges the policy makers 'by insisting on shifting the geography of reason from the soft chairs of government policy makers' offices to the ground of the shack settlements where everyone can participate in what they call the "University of Abahlali"' (Gibson 2008:707; see also Gibson 2007, 2011a, 2011b).

If there are an estimated 182 informal settlements in Johannesburg alone and almost 2000 such settlements in South Africa (Harber 2011:227; cf. also Vellem 2014:207), and if these settlements, inner cities and urban townships host millions of disenfranchised inhabitants who lack a right to the city, doing urban public theology without integrating the insights from both scholarly and popular movements reflecting on, and activating for, the right to the city, would not only be hugely irresponsible, but it would also gain little legitimacy on the part of those scholarly and popular movements.

Consequently, it is at this point that we want to recognise the work of Rubin Phillip, current bishop of the Anglican Diocese of Natal, as an exemplar of the kind of urban public theological praxis that we have in mind. Not only has he been providing moral and spiritual support to an urban social movement such as AbM in the city region of Durban/ eThekwini, but he continues to learn from the struggles and strategies of its members - to that extent that they have become prominent interlocutors for his own theological praxis (see Abahlali baseMjondolo 2007; Matsaneng 2007; Mgaqelwa 2013; Phillip 2008; Phillip \& KwaZulu-Natal Church Leaders' Group 2013; Pomfret 2010).

Although not specifically locating his concerns in contexts of the urban, we at the same time want to acknowledge the work of South African black theologian Takatso Mofokeng, who already some years ago lamented the way in which the commodification of all spheres of life has severely affected the South African black (urban) working class in particular (see Mofokeng 1991). Yet, for us, as an alternative to such reality, which ought to inspire a South African urban public theological praxis-agenda, the prophetic vision of Isaiah especially comes to mind. In Chapter 65 of this prophetic book, the prophet speaks of a city with high levels of access to economic well-being, decent housing, basic health care, and participation in, and ownership of, processes that could sustain livelihoods. In the prophet's vision, the poor are not to be mere outsiders looking in, but neighbours and full citizens, benefiting fully as partakers of urban resources, in equal and just ways with everyone else.

This theme is indeed surfacing a clear requirement for an ever-deepening urban public theological praxis-agenda, which ultimately has to grapple with the challenge of how to activate and mobilise actors of faith as solidarity partners of 'right to the city' movements in the presentday South African context.

\section{A reclaiming of the commons}

The 'tragedy of the commons' - a theory developed by ecologist Garrett Hardin (1968) - has become a central concern in the work of many political economists, ecologists and social change agents. The basic assertion is that the actions of individuals and groups not valuing the well-being of society at large, and advancing their own self-interests at the expense of the common good of all, will deplete common resources. It suggests that over-consumption by the few - of environmental and material resources - is depleting common resources in ways that are fundamentally unsustainable.

Although not a uniquely urban phenomenon, cities are suffering a 'tragedy of the commons' in extreme ways. This is evident from crises related to governance by a few at the expense of the masses, ever-deepening economic disparities and exclusions, challenges related to urban environmental and waste management, and the privatisation and militarisation of public spaces. Individualism and privatised interests are expressions of this tragedy at the expense of the common or public good.

Following Hardin's notion of a 'tragedy of the commons', David Harvey (2012:80) is of the opinion that '(c)apitalist urbanization perpetually tends to destroy the city as a social, political and liveable commons'. However, scholars such as Elinor Ostrom (1990; also Ostrom et al. 1999) and Drucilla Cornell (2014) have also reflected on the tragedy of the commons but have gone further to consider ways in which the commons can be reclaimed. In their considerations, they demonstrate how local communities are able to make decisions and develop solutions that could turn the tragedy into hopeful alternatives.

Ostrom (1990), in a publication some years ago, explored alternative solutions to privatisation by uncovering models of self-organisation and self-governance through what she calls the management of 'common pool resources' (CPRs), based on collective actions and high levels of trust. And in her presentation more recently at the 10th Biennial Consultation of the Institute for Urban Ministry held in Pretoria, City of 
Tshwane, Cornell (2014), in drawing on Rosa Luxemburg, Massimo De Angelis and S'bu Zikode from the alreadymentioned urban shack dwellers movement Abahlali baseMjondolo, proposed the possibility of creating, in the present-day South African political and economic context, a 'people's outside' or 'commons'. In finding Zikode's idea of a 'living communism' particularly attractive - as conceptual and practical alternative to 'socialism as traditionally understood through state ownership' - she consequently suggested, as a central task of reclaiming the commons, 'the effort to maintain constituent power in the hands of the people [read "shack dwellers"], so that new forms of organization are formed, both to prevent resources to be taken away from the people and to redistribute them' (Cornell 2014:10).

We may, at this point, make two further connections in this brief identification of 'a reclaiming of the commons' as a third thematic concern for a South African urban public theological praxis-agenda. The first is to the relevance of the work of the Sustainability Institute located at the outskirts of the university town of Stellenbosch. Projecting itself as 'an international living and learning centre' aiming to provide 'a space for people to explore an approach to creating a more equitable society that lives in a way that sustains rather than destroys the eco-system within which all society is embedded (Sustainability Institute n.d.), an important part of the work of the Institute has been to rethink the notion of urbanism through the conceptual apparatus of 'sustainability'. Importantly, however, the Institute's approach towards such rethinking has, similar to the idea of 'the commons', been to criticise the way in which the depletion of the urban commons by the middle-class and rich elite remains a chronic problem in South Africa, and related to this, to problematise the way in which the conceptual and practical challenge of sustainability has remained marginal to scholarly and policy work on the urban in South Africa (see Swilling 2004; Swilling \& Annecke 2012:107-136).

Bringing us to the second of the two connections, it may be rather obvious that an important conceptual link ought to exist between the second of our identified thematic concerns on the 'right to the city' and the 'reclaiming of the commons' concept. As a result, such a conceptual link is, for instance, importantly found in the already-mentioned work of David Harvey, in which a whole chapter is devoted towards conceptualising this link. At the same time, however, here it also becomes important to note how Harvey cautions against a simplistic connection. His discussion suggests that profound reflection ought to be involved about the nature of the workings of 'capitalist urbanisation' and how this calls for the conceptualisation of viable socio-economic alternatives and intense political action to realise such alternatives (see Harvey 2012:67-88).

Clearly, then, the complexity of the issues at stake, as the conceptual work of Harvey suggests, but also the work on sustainability and the challenge of 'the commons', poses a very important further challenge for a South African urban public theological undertaking on its anticipated way towards conceptual deepening. While it could well be assumed that South African urban public theologies of the future will, from the vantage-point of their connection to vulnerability and contested urban spaces, almost by definition be involved in efforts to articulate, defend or advance the possibility of the commons, much is to be gained from an openness to learn from, and engage in, conversation with the kind of theoretical work that we have started to identify in this sub-section.

The work of liberation theologies as critique against a 'developmentalism' that locate resources with a few at the expense of the global poor (Gutierrez 1973; cf. also Hennelly 1989:189; Pottenger 1989:103); the work of a black theologian such as Mofokeng (1991) who asserts a vision of communality and solidarity as key concepts in developing local, self-reliant communities and economies; and the work of theologians such as John Cobb (1992), Matthew Fox (2000), Annalet van Schalkwyk (2008) and Ernst Conradie (2011), in which they have been developing alternative visions on sustainability, economics and ecology, are all important resources to be brought into conversation with scholars such as Harvey, Ostrom, Swilling, Annecke, Cornell and others, as an urban public theological praxis-agenda begins to participate in conversations and actions to reclaim the commons.

\section{Making good cities}

In recent years theorists of the urban from different disciplines have started to use language of 'city-making' that will help facilitate the conceptualisation of 'good cities'. In the language of these theorists the making of cities should not be regarded as the sole mandate of politicians, planners or technocrats, but it should be open to all people to imagine the notion of the 'good city'. One expression of such a position can be found in the work of planning theorist, Leonie Sandercock, who, according to Christopher Baker (2007:32) develops a 'utopian vision of the city as cosmopolis'. Her imagined city is:

... a city of bread and festivals, where those who don't have the bread aren't excluded from the carnival ... where social justice is more prized than a balanced budget ... where no one flaunts their authority and no one is without authority ... where I don't have to translate my 'expertise' into jargon to impress officials and confuse citizens. (Sandercock 2003:207-208)

Baker, in his appreciation of Sandercock's contribution, points out that the difference between her utopia and the 'physical, technocratic utopias' of modernist planning is that she 'realizes that her perfect society will never be achieved. It can only ever be in the making ...' and rather derives from an understanding of 'cosmopolis' as:

... a commitment to an inclusive style of politics, and an educational process; an attitude of mind that is prepared to accept the existence of difference and the emergency of hybridity as a consequence of allowing the Other (that is, the global migrant) to share the same urban space. (Baker 2007:32)

We may note, at this point, how attempts to give rise to the notion of the 'good city' are, in a sense, a direct response to 'the tragedy of the commons'. And while the example of 
Sandercock may be appealing in this regard, an even more appealing example could be found in the work of British geographer Ash Amin. In contrast to Sandercock's 'utopian dream' of the good city, as something that can only ever be in the making and, in that sense, something that can in fact never be achieved, Amin, in his conceptualisation, hinges on the idea of what he calls 'a pragmatism of the possible' based on continual efforts 'to spin webs of social justice and human well-being and emancipation out of prevailing circumstances' (Amin 2006:1010). He thereupon continues to explain:

\begin{abstract}
Such an approach accepts that utopia is not a dream of the attainable, but an 'impossible place' following Foucault, expressing a 'hope in the not-yet', based on many practices 'of transformative intervention' that strive 'to give and find hope through an anticipation of alternative possibilities or potentialities' ... It retains the original idea of an anticipated society, but now harnessed to careful obligations in the arena of personal politics, insurgent design, collective responsibilities and human rights ... It accepts that the constitutive multiplicity of our times is both capitalist entrapment and opportunity for a plural democracy drawing on possibilities that are more than capitalist trickery. (Amin 2006:1010-1011)
\end{abstract}

Founded on such sense of realism and possibility of human agency, Amin, in his further reflection on the notion of the 'good city', conspicuously proceeds from a rather pessimistic view of contemporary cities as not constituting 'sites of community, happiness and well-being, except perhaps for those in the fast lane, the secure and wellconnected, and those excited by the buzz of frenetic urban life'. For the larger majority, he contends, 'cities are polluted, unhealthy, tiring, overwhelming, confusing ... [and] alienating' (Amin 2006:1011).

However, Amin does not want to relinquish the idea that 'the urban remains an enormously significant formative arena', which, as the 'supremely visible manifestation of difference and heterogeneity', offers 'some possibility to the millions of dispossessed, dislocated and illegal people stripped of citizenship to acquire some political capital' (Amin 2006:1012). As a result, this belief in the emancipatory potential of the urban leads him to imagine the possibility of 'an ever-widening habit of solidarity' that could be 'built around different dimensions of the urban common weal', as a way towards nurturing an 'urban public culture ... towards outcomes that benefit the more rather than the few, without compromising the right to difference that contemporary urban life demands' (Amin 2006:1012).

Space does not allow us here to dwell on the details of Amin's further argumentation other than to briefly (and rather unsatisfactorily in this sense) point to his proposal of four interrelated 'registers of urban solidarity', which he suggests in conclusion could become real possibilities through which the ideal of the good city - a 'practical urban utopianism' (Amin 2006:1013) - may start to manifest. Constituting possibilities that he foresees will be realised through the acts and attitudes of government, the media, opinionmakers, civic organisations, communities and citizens' (Amin 2006:1012), this would, firstly, entail the possibility of 'repair', whereby the benefits of modern technology would be used to 'ensure universal and affordable access to the basics of shelter, sanitation, sustenance, water, communication, mobility and so on' (Amin 2006:1013-1015); secondly, the possibility of 'relatedness', whereby strangers will be recognised and welcomed in a movement that would return 'the city's public spaces to mixed public use, without excessive surveillance, gating, privatisation or humiliation of minorities, but with adequate security against the violent or against corporatist homogeneity' (Amin 2006:1015-1017); thirdly, the possibility of 'rights', as reflected in 'right to the city' discourses (Amin 2006:1017-1019); and, finally, the possibility of 're-enchantment', to be realised more specifically in the revitalisation of urban public spaces as open 'sites that combine pleasure with the skill of negotiating difference' and 'acts as the gauge of civic ownership and civic behaviour in a city' (Amin 2006:1019-1020).

In opting for the notion of the 'good city' as fourth thematic concern, our brief outline of the contribution of Amin in particular, suggests that conceptual work related to this notion involves contribution to an all-encompassing sociological and philosophical idea-construct regarding the urban that necessarily incorporates themes such as 'the right to the city' and 'a reclaiming of the commons'. Significantly, however, as an undertaking in 'realistic' or 'practical urban utopian' thinking (to follow the conceptual choice of Amin) that should motivate and inspire, it should not escape our attention that this is a terrain to which Christian public theological scholarship has (perhaps not surprisingly!) started to make a contribution. We find this contribution to date best articulated in work by British scholars Elaine Graham and Stephen Lowe, in which they explore the contours of 'urban theology as public theology' by focusing on the concept of the 'good city' and the question of the role of the church and faith communities in achieving this ideal. In particular, by taking as their point of reference the two quite remarkable reports that were commissioned by the Church of England respectively in the 1980s and 2000s, Faith in the city and Faithful cities, Graham and Lowe give evidence of ventures in doing urban public theology that, in their own right, offer powerful critiques, imaginations and alternatives for cities today (see Graham 2008, 2009; Graham \& Lowe 2009). As such, they give evidence of ventures in doing urban public theology that not only cannot be ignored by an anticipated South African urban public theological praxis-agenda, but that also well deserves the attention of utopian scholars such as Amin and others outside theology in view of greater interand transdisciplinary conversation.

\section{Actors of faith in relation to urban social life}

One could rightly begin to speak today of a 'religious turn' in counterpoint thinking about the urban, notably in our own South African and African context. In this regard, we already started to allude to the existence of such a 'religious turn' in our first article in this special collection, when we juxtaposed the work of a non-theological scholar such as Tanja Winkler, 
of an author of non-fiction such as Christa Kuljian, of an independent policy research and advocacy organisation such as the Centre for Development and Enterprise, and of a prominent think-tank from the counterpoint such as the African Centre for Cities with the present lack of a public theological focus on, or engagement with, the urban in South Africa (see Swart \& De Beer 2014).

We do not have the space in this article to elaborate in detail on the respective arguments and perspectives that are offered by such different expressions of the 'religious turn'. However, we find in their empirical interrogation of how actors of faith - notably churches but also actors from other faith traditions - are influencing and shaping urban social life in South Africa but also Africa at large a most important fifth thematic contour for a South African urban public theological praxis-agenda. Thus, over and above the urban public theological task to make a theological contribution to the first four themes that we have highlighted, such conceptual work crucially needs to be informed by the empirically founded perspectives emanating from the fifth theme's concern with actors of faith's actual social presence and influence in contexts of the urban.

Against the backdrop of such an emphasis on a fifth thematic contour, there should be no doubt that our agenda is one that wants to stretch the traditional competencies and preoccupation with philosophical and systematic theological speaking that determines current public theological practice, in South Africa but also internationally. In contrast, our agenda is one that wants to strike a new balance between the 'real' and the 'ideal', between new normative conceptualisations and visions, on the one hand, and factual information based on sound social research methodology on the other, between what is idealised about the role and contribution of churches and other actors of faith and the actual realities on the ground.

Whilst a similar contribution by South African public theological scholarship is conspicuously lacking at present, and for what it is worth by other fields and foci in South African theological scholarship as well, urban public theology as a new agenda in South Africa can already find important inspiration and direction in how others outside the disciplinary realm of theology - with specific reference to the examples that we have mentioned - are showing a new interest in religion as an actor and force in the contemporary South African and African landscape. Clearly, while the existing work at our disposal gives socio-empirical evidence of less desirable and dynamic expressions of faith and religion in contexts of the city and the urban, and of less promising prospects of religion and actors of faith becoming forces of progressive social change (cf. Rakodi 2014; Winkler 2008a, 2008b), there is also much to draw from in view of an action-oriented, problem-solving and normatively inclined South African urban public theological praxis-agenda. As perspectives on the 'urban real', both in South Africa and Africa at large, one finds in the existing contributions sophisticated demographic descriptions of how different actors of faith are today occupying urban spaces (cf. Bernstein \& Rule 2010; Rakodi 2014; Winkler 2008a, 2008b), of how such actors cannot be ignored in any concern with the urban as membership of their groups 'is more common than of any other type of organisation' (Rakodi 2014:82), of how such actors are shaping and influencing urban social life in all kinds of ways by giving meaning, identity, refuge, hope and some kind of livelihood support to many in distressed urban contexts (cf. Bernstein \& Rule 2010; Kuljian 2013; Rakodi 2014; Winkler 2008a, 2008b), of how such actors are, in some instances, also shaping urban political life (Rakodi 2014:96-97), and of how, amongst such actors, Pentecostal type churches in particular are emerging as a new force of 'entrepreneurial energy' (Bernstein \& Rule 2010:123).

Whilst we are merely providing a glimpse here of the new rich layer of perspectives that are emerging from research work on religion and the urban outside the domain of South African theological scholarship, it is of great importance to, at this point, acknowledge the concluding comment from one of these existing contributions about the challenge still lying ahead in meeting what still remains a considerable knowledge gap. In the words of this author:

The gaps in our knowledge are enormous but because of the influence of recent trends in development theory, the increased acceptability of mixed methods approaches to research, and the emergence of improved conceptual and analytic frameworks for understanding religion and society ... we are better placed today to develop an improved understanding of what religion means for its adherents; the ways in which it influences urban residents' expectations and interactions with each other'; the relationships between religion and other dimensions of difference and inclusion or exclusion; the roles of religious organisations in providing welfare, social support and services, as well as in politics; and the influence of religious beliefs and actors in blocking or contributing to wider processes of urban change. (Rakodi 2014:102)

We want to conclude this section by identifying it as a core task of a new urban public theological praxis-agenda in South Africa to make a noticeable contribution towards meeting the existing gaps in knowledge. In fact, we want to go so far as to say that, without such a concerted effort, this new agenda will gain little legitimacy and recognition within the wider ambit of intellectual and scholarly concern with the urban. Not least, however, in order to make such a contribution and become a knowledgeable conversant of its own topical focus on the urban, a South African urban public theological praxis-agenda should find an important reminder in the above quote with regard to what we have already started to allude at. Such a contribution cannot mean business as usual, but it will ask of an urban public theological praxis-agenda to notably expand its methodological scope and expertise, and to show a new willingness to, in a learning mode, involve itself in new spaces of interdisciplinary and transdisciplinary scholarship - in line with the hermeneutical position that we have ourselves adopted (see Swart \& De Beer 2014). 


\section{Conclusion}

This article, by adopting 'a fusion of horizons' as a hermeneutical catch-phrase, sought to incarnate public theological discourse in challenging urban contexts, but also very intentionally in the counterpoint where scholarly, civic and popular engagements with urban challenges meet. Ours is not a neutral contribution but locates itself very specifically in a praxis-approach that endeavours to engage the city through an on-going dance of action and reflection, asking: Whose city is it? Who has a right to the city? Whose knowledge shapes the city? And how do people and institutions of faith - particularly those of us who seek to embody Jesus - participate with a wide range of other partners, to reclaim the commons and make space for all, in order to make good cities that resemble good news in rather concrete ways?

\section{Acknowledgements Competing interests}

The authors declare that they have no financial or personal relationship(s) that may have inappropriately influenced them in writing this article.

\section{Authors' contributions}

S.d.B. (University of Pretoria) and I.S. (University of South Africa) contributed equally to the conceptualisation and writing of the article. I.S. was responsible for all revisions and prepared the article for submission.

\section{References}

Abahlali baseMjondolo, 2007, '9 October meeting with church leaders to discuss solidarity in the wake of the police attack on AbM on 28 September', in Abahlal baseMjondolo: Home of the Abhlali baseMjondolo Shackdwellers Movement South Africa, viewed 21 August 2014, from http://abahlali.org/node/2743/

Amin, A., 2006, 'The good city', Urban Studies 43(5/6), 1009-1023. http://dx.doi. org/10.1080/00420980600676717

Baker, C.R., 2007, The hybrid church in the city: Third space thinking, Ashgate, Aldershot. Bakke, R., 1997, A Theology as big as the city, InterVarsity Press, Downers Grove, IL.

Bernstein, A. \& Rule, S., 2010, 'Flying under South Africa's radar: The growth and impact of Pentecostals in a developing country', in P.L. Berger \& G. Redding (eds.) The hidden form of capital: Spiritual influences in societal progress, pp. 91-131, Anthem Press, London.

Cobb, J.R., 1992, Sustainability: Economics, ecology and justice, Orbis Books, Maryknoll, NY.

Conradie, E.M., 2011, Christianity and earthkeeping: In search of an inspiring vision Sun Press, Stellenbosch.

Cornell, D., 2014, 'Can there be a people's commons? The significance of Rosa Luxemburg's "The Accumulation of Capital" for politics in South Africa', paper presented at the 10th Biennial Consultation on Urban Ministry, Institute for Urban Ministry, Pretoria, City of Tshwane, 15-17 July.

Fox, M., 2000, Original blessing: A primer in creation spirituality presented in four paths, twenty-six themes, and two questions, Jeremy P. Tarcher/Putnam, New York, NY.

Gibson, N.C., 2007, 'Zabalaza, unfinished struggles against apartheid: The shackdwellers' movement in South Africa', Socialism and Democracy 21(3) 60-96. http://dx.doi.org/10.1080/08854300701599817

Gibson, N.C., 2008, 'Upright and free: Fanon in South Africa, from Biko to the shackdwellers' movement (Abahlali baseMjondolo)', Social Identities 14(6), 683-715. http://dx.doi.org/10.1080/13504630802462802

Gibson, N.C., 2011a, 'What happened to the "promised land"? A Fanonian perspective on post-apartheid South Africa', Antipode 44(1), 51-73. http://dx.doi.org/10.111 $1 / \mathrm{j} .1467-8330.2010 .00837$

Gibson, N, 2011b, Fanonian practices in South Africa: From Steve Biko to Abahlal baseMjondolo, Palgrave Macmillan, New York, NY.
Görgens, T. \& Van Donck, M., 2012, 'Exploring the potential of the "right to the city" to integrate the vision and practice of civil society in the struggle for the socio-spatial transformation of South African cities', paper presented at the conference Strategies to overcome poverty and inequality: Towards Carnegie III, 03-07 September 2012, viewed 10 April 2014, from http://isandla.org.za/ III, 03-07 September
publications/161/

Graham, E., 2008, 'What makes a good city? Reflections on urban life and faith', International Journal of Public Theology 2(1), 7-26. http://dx.doi. org/10.1163/156973208X256420

Graham, E., 2009, 'Theology in the city: Ten years after Faith in the City', in E. Graham, Words made flesh: Writings in pastoral and practical theology, pp. 189-206, SCM Press, London.

Graham, E. \& Lowe, S., 2009, What makes a good city? Public theology and the urban church, Darton, Longman \& Todd, London.

Gutierrez, G, 1973, A theology of liberation: History, politics and salvation, Orbis Books, Maryknoll, NY.

Hankela, E., 2014, Ubuntu, migration and ministry: Being human in a Johannesburg church, Brill, Leiden. http://dx.doi.org/10.1163/9789004274136

Harber, A., 2011, Diepsloot, Jonathan Ball, Johannesburg/Cape Town.

Hardin, G., 1968, 'The tragedy of the commons', Science 162(3859), 1243-1248. http://dx.doi.org/10.1126/science.162.3859.1243

Harvey, D., 2012, Rebel cities: From the right to the city to the urban revolution, Verso, London/New York, NY.

Hennelly, A.T., 1989, Theology for a liberating church: The new praxis of freedom, Georgetown University Press, Washington, DC.

Huchzermeyer, M., 2011, Cities with 'slums': From informal settlement eradication to a right to the city in Africa, Juta/UCT Press, Cape Town.

Isandla Institute, n.d., What we do, viewed 05 August 2014, from http://isandla.org. za/about/what-we-do/

Kuljian, C., 2013, Sanctuary: How an inner-city church spilled over onto a sidewalk, Jacana, Auckland Park.

Lefebvre, H., 1996, Writings on cities, translated and introduced by E. Kotman \& E. Labas, Blackwell, Oxford.

Matsaneng, L., 2007, 'Sunday Tribune: Police action incurs church wrath', in Abahlali baseMjondolo: Home of the Abhlali baseMjondolo Shackdwellers Movement South Africa, viewed 21 August 2014, from http://abahlali.org/node/2695/

Mgaqelwa, A., 2013, 'Daily Dispatch: Christian leaders won't remain silent for Zuma', in Abahlali baseMjondolo: Home of the Abhlali baseMjondolo Shackdwellers
Movement South Africa, viewed 21 March 2014, from http://abahlali.org/ node/12768/

Mofokeng, T.A., 1991, 'Human values beyond the market society: A black working class perspective', Journal of Theology for Southern Africa 72, 64-70.

Ostrom, E., 1990, Governing the commons: The evolution of institutions for collective action, Cambridge University Press, New York, NY. http://dx.doi.org/10.1017/ CBO9780511807763

Ostrom, E., Burger, J., Field, C.B., Norgaard, R.B. \& Policansky, D., 1999, 'Revisiting the commons: Local lessons, global challenges', Science 284(5412), 278-282, http:// dx.doi.org/10.1126/science.284.5412.278

Phillip, R., 2008, 'Bishop Rubin Phillip's unfreedom day speech', speech delivered to Abahlali Basemjondolo event for unfreedom day, Kennedy Road Community Hall, Clare Estate, Durban, 27 April, in Abahlali baseMjondolo: Home of the Abhlali baseMjondolo Shackdwellers Movement South Africa, viewed 21 August 2014, from http://abahlali.org/node/3489/

Phillip, R. \& KwaZulu-Natal Church Leaders' Group, 2013, 'Destroying our lives - in Cato Crest', Statement of Solidarity from Bishop Rubin Phillip \& the KwaZulu Natal Church Leaders' Group, in Abahlali baseMjondolo: Home of the Abhlali baseMjondolo Shackdwellers Movement South Africa. http://abahlali.org/ node/12318/

Pieterse, E., 2014, 'Epistemological practices of Southern Urbanism', paper presented at the ACC Academic Seminar, 21 February, viewed 18 April 2014, from http://www. africancentreforcities.net/wp-content/uploads/2014/02/Epistemic-practices-ofsouthern-urbanism-Feb-2014.pdf

Pieterse, E. \& Parnell, S., 2014, 'Africa's urban revolution in context', in S. Parnell \& E. Pieterse (eds.), Africa's urban revolution, pp. 1-17, Zed Books, London.

Pomfret, E., 2010, 'A bishop's pursuit of justice for South Africa's shack dwellers', in Anabaptist Network in South Africa (ANISA), viewed 21 August 2014, from http:// anisa.org.za/news/20100604/bishops_pursuit_justice_south_africas_shack dwellers

Pottenger, J.R., 1989, The political theory of liberation theology: Towards a reconvergence of social values and social science, State University of New York Press, Albany, NY.

Rakodi, C., 2014, 'Religion and social life in African cities', in S. Parnell \& E. Pieterse (eds.), Africa's urban revolution, pp. 82-109, Zed Books, London.

Saunders, D., 2011, Arrival city: The final migration and our next world, Vintage, Toronto, ON.

Sustainability Institute, n.d., Sustainability Institute, viewed 07 August, from http://www. sustainabilityinstitute.net/

Swart, I. \& De Beer, S., 2014, 'Doing urban public theology in South Africa: Introducing a new agenda', HTS Theological Studies 70(3), Art. \#2811, 14 pages. http://dx.doi. org/10.4102/hts.v70i3.2811

Swilling, M., 2004, 'Rethinking the sustainability of the South African city', Development Update 5(1), 215-242. 
Swilling, M. \& Annecke, E., 2012, Just transitions: Explorations of sustainability in an unfair world, United Nations University Press/UCT Press, Claremont/New York, NY.

Tonkiss, F., 2012, 'Informality and its discontents', in M. Angélil \& R. Hehl (eds.), Informalize! Essays on the political economy of urban form, pp. 55-70, Ruby Press, Berlin.

United Nations, Department of Economic and Social Affairs, Population Division (UNDESA), 2012, World Urbanization Prospects: The 2011 Revision, United Nations, New York, viewed 06 August 2014, from http://esa.un.org/unup/Documentation/ final-report.htm

Van Schalkwyk, A., 2008, 'Women, ecofeminist theology and sustainability in a postapartheid South Africa', Journal of Theology for Southern Africa 130(March), 6-23.

Varley, A., 2013, 'Postcolonialising informality?', Environment and Planning: Society and Space 31(1), 4-22. http://dx.doi.org/10.1068/d14410

Vellem, V., 2014, 'Life-giving assets at a Johannesburg informal settlement: Black faith and the false gods of multi-culturalism in the twenty-first century', in R.D. Smith, W. Ackah \& A.G. Reddie (eds.), Churches, blackness, and contested multiculturalism: Europe, Africa, and North America, pp. 207-212, Palgrave multiculturalism: Europe,
MacMillan, New York, NY.
Winkler, T., 2008a, 'Super-sizing community development initiatives: The case of Hillbrow's faith sector' International Journal of Public Theology 2(1), 47-69. http://dx.doi.org/10.1163/156973208X256448

Winkler, T., 2008b, 'When God and poverty collide: Exploring the myths of faithsponsored community development', Urban Studies 45(10), 2099-2116. http:// dx.doi.org/10.1177/0042098008094875

Zikode, S., 2007, 'The shackdwellers movement of Durban', in P. Bond, H. Chitonge \& A. Hopfmann (eds.), The accumulation of capital in Southern Africa: Rosa Luxemburg's contemporary relevance, Proceedings of the Rosa Luxemburg Seminar 2006 and the Centre for Civil Society's colloquium on Economy, Society and Nature, Berlin, Rosa Luxemburg Foundation and Durban, Centre for Civi Society, pp. 163-165, viewed 12 June 2014, from http://ccs.ukzn.ac.za/files/ RL\%20Capital-africa.pdf

Zikode, S., 2013, 'Despite the state's violence, our fight to escape the mud and fire of South Africa's slums will continue', The Guardian, viewed 21 July 2014, from http:// www.theguardian.com/commentisfree/2013/nov/11/south-africa-fight-decenthousing-assassination 